\title{
The optimized model of enterprise internal accounting control in
}

\section{network environment}

\begin{abstract}
Xiaojie Li
Shaanxi institute of international trade\&commerce, Xianyang Shaanxi 712046

Fund project: Research on the application of asset securitization in Shaanxi local government debt management
\end{abstract}

Keywords: network environment accounting control; optimization model

\begin{abstract}
Network Environment Enterprise Internal Accounting Control relying on network information technology and large data technology to achieve the control environment in the information-based, automated control mode, the control of the proliferation, control the focus of pluralism. The current network environment in the face of new opportunities and challenges, enterprise internal accounting controls the prevailing data disclosure vulnerability, the level of informationization is not high, management systems are not up to the standard, control mechanism is not sound issues, the constraints of internal accounting control systems running efficiently. Currently facing new opportunities and challenges, the network environment the enterprise internal accounting control is common data leakage hidden trouble, the informationization level is not high, management system is not standard, the problem of control mechanism is not sound and so on, restricts the efficient operation of the internal accounting control system. This should be the establishment of a sound network information risk prevention and control mechanisms to build accounting control information sharing, and establish an integrated accounting control system and to improve the internal corporate accounting control mechanisms, so as to further promote the network environment enterprise internal accounting control mode the optimization.
\end{abstract}

\section{Introduction:}

As the Internet the rapid development of information technology, enterprise internal accounting controls are also faced with new challenges and opportunities, and enterprises enjoy the convenience of network environment, efficiency, timeliness, accounting control experience should be accompanied by increased awareness, the establishment of risk prevention and control mechanisms, pay close attention to the network environment of internal accounting controls for the security issues, information issues in this enterprise in a networked environment the efficient functioning of the necessary prerequisites.

\section{The network environment for Enterprise Internal Accounting Control Mode}

Network Environment enterprise internal accounting control system can be used large data analysis technology and the sharing of information resources platform for accounting data information, thereby breaking the traditional control mode information is passed to the level of the barriers of distance and obstacles, and fostering enterprises internal accounting information of flexibility, timely sharing and exchange.

The enterprise network environment of internal accounting controls no longer excessive reliance 
on accounting personnel management and operation, but emphasized the computer applications for accounting controls the implementation of the measures of the role, which helps businesses achieve internal accounting control of automation.

Compared to the traditional ways to manual control computer programming-led accounting controls at the information accuracy, normative, timeliness of significant advantages in terms of that helps organizations achieve significant savings in the cost of labor, and thereby promote enterprise internal production resources optimization configuration.

At the same time, also should pay attention to the computer automation in the process of accounting control can occur due to perform password stolen information leakage hidden trouble.

Openness, sharing network environment makes the enterprises' internal accounting control scope expanded development possible, under the new era of enterprise internal accounting control objectives should focus on the overall global and industry, which requires the enterprise in the financial sector of business include the category of accounting control, strengthen the administrative personnel and technology, production personnel at various levels of information regulation.

With the enterprise overall as the scope and the staff as the control object of accounting control system can not only minimize the risk of enterprise accounting information disclosure, also can make all the staff to the enterprise overall financial accounting information sensing, while realize the accounting information transparency, openness to stimulate staff's work enthusiasm and enterprise recognition and loyalty.

Based on network environment of the enterprise internal accounting control is mainly with the aid of a computer system and data analysis platform to realize the accounting information collection, processing, output, sharing, this way of embedded business process automation control the accuracy of the source of accounting information demand is higher.

Enterprise Internal Accounting Control is also focused on the traditional unitary accounting control gradually expanding to include accounting, computer systems, economic activity in the pluralistic control.

\section{The challenge for the enterprise internal accounting control under the network environment}

Network information technology in the enterprise internal accounting control in openness, sharing, information network environment at the same time, also makes the accounting information faces many security hidden danger.

First, the network environment makes the enterprise inside and outside information interaction between becomes more frequent, enterprise fully absorbed in the outside world of information resources at the same time also means that the internal accounting information faced with the risk of being stolen or leaked.

Many criminals will grow into the application software of Trojan virus taken advantage of the black into the enterprise internal accounting control system, the accounting information is often directly related to the survival of the enterprise, which greatly contributed to the enterprise safe hidden trouble, Second, many enterprises in the use of the network environment at the same time did not pay attention to safety protection, computer terminal to the criminals to chink in the wall.

Most companies did not set related to computer security maintenance jobs and staff, rely on common computer security guards and anti-virus software is difficult to effective defense against outside intrusion.

Some large enterprises has been basically established internal accounting information control mechanism, and the present enterprise's informatization level is not high, intelligent, automation control is urgently needed to solve problems. 
On the one hand, the small and medium-sized enterprise accounting management concepts backward, will be limited to the short-term economic interests, the long-term business benefits of accounting information control to turn a blind eye, even part of the cottage industry of enterprise accounting control is still stay in manual control level, set up the digital information resources lead to accounting accounts did not mix.

On the other hand, enterprises accounting controls the level of informationization of low bound to affect a large number of information resources for the dissemination and sharing of speed, and multi-sectoral information between the barriers to communication and finally resulted in the production of enterprises and the wasting of resources.

Enterprises' internal accounting control of colleges and universities operation without strict management system, especially in the network environment, accounting personnel faces many outside the temptation of utilitarianism and the impact of multi-cultural value, easy to breed the bad behavior, seek personal gain by position if not to the accounting management system to regulate and optimize is bound to the enterprise into multiple security hidden danger.

Enterprises' internal accounting control of colleges and universities operation without strict management system, especially in the network environment, accounting personnel faces many outside the temptation of utilitarianism and the impact of multi-cultural value, easy to breed the bad behavior, seek personal gain by position if not to the accounting management system to regulate and optimize is bound to the enterprise into multiple security hidden danger.

In addition, because of the lack of standardization, the strict system of supervision and accounting control work in the employees personal will appear under the domination of the characteristics of randomness, and even some accounting control do not conform to the requirements of the industry standard, it is difficult to promote enterprise development toward normalization, standardization and roads.

Enterprise accounting control mechanism in structure changes have taken place under the network environment, under the guidance of the network environment, the enterprise internal accounting control of the structure of mechanical to the implementation of the change, the accounting control system, from closed to open, the accelerating information sharing and transmission at the same time also the enterprise in higher safety hidden trouble.

While the current enterprise internal accounting control mechanism of the imperfect became the impact on your business more efficient functioning of the important factors. Some of the enterprises in order to save on operational costs, accounting control mechanism does not comply with industry standards and state system specification, in actual operation is not strictly in accordance with the request of the country relevant measures and provisions for accounting controls.

Some enterprises in order to save operating costs, accounting control mechanism do not conform to the requirements of the industry standard and the system of national standards, not in the actual operation in strict accordance with the requirements of related measures and regulations of the state of accounting control. The reason mainly lies in the enterprise to short-term interests as the goal, ignore the important mechanism of normative control, which makes many enterprises into formal accounting control mechanism construction.

\section{The optimization of enterprise internal accounting control mode under the network environment}

Enterprise according to the characteristics of openness, sharing network environment, formulate the corresponding risk control mechanism.

On the one hand, strengthening of internal accounting personnel of administrative oversight and 
monitoring system to avoid staff used for private interests, the implementation of the responsibility system to vigorously pursue the accounting information disclosure of such acts.

In strict compliance with corporate internal administrative supervisory system and the staff on the basis of the standards of conduct for the strengthening of the Government by the supervisory authorities, promptly discover business accounting staff negligence of duties.

On the other hand, to strengthen the technical supervision, cultivate attract a group of computer risk prevention capability of high-quality personnel.

The Enterprise Computer Hardware Device and Device zone of the physical environment be tightly controlled to ensure the normal operation of the hardware devices to prevent equipment failures result in loss of data.

At the same time it is necessary to continuously enhance the accounting software system for correctness and completeness, the establishment of a higher level of security firewall, avoid the lawless elements penetrated the enterprise accounting information theft.

Within the framework of world business accounting information in a network environment under the computerization, automation, information, intelligence, has become a general trend of social and economic development. The achievement of accounting information in the enterprise between sectors within the resource sharing is a network environment sustainable development. So enterprises should attach great importance to the construction of accounting information sharing platform for the enterprise the important value of long-term economic interests. First of all, the accounting department to the enterprise each department to the accounting information sharing, as each department work plan and budget in the important reference basis. All departments need to report to the financial data and information to take electronic version, in order to realize data information in the storage, transmission, access to convenient. Secondly, the accounting information openness, transparency, relied on big data analysis techniques, the various departments of the accounting information integration, to build including business in all sectors of the accounting information sharing platform as a guarantee for the dissemination of information of the immediacy and accuracy.

Information technology is the support network environment enterprise internal accounting control of information, the basic conditions for automation, set the network technology applications to the accounting business workflow reorganization optimization of giving full play to the new situation of the internal control system of accounting benefits have an important role to play.

On the one hand, the establishment of a network for the needs of the environment and database technologies in the computer object-oriented technology designed to optimize the operator interface, thus helping to improve the financial and accounting information in the various sectors with a circulation of convenient and effective and operability.

On the other hand, give full play to the advantages of network information technology for corporate purchases, production, sales and operational aspects of the establishment of financial integration information platform, all corporate accounting information in Report forms submitted directly to integration platform.

At the same time, according to the level of the Organization as well as the positions of the different functions of the personnel to set the appropriate user rights, in a shared accounting information at the same time, to safeguard the security of the platform.

Change and improve the enterprise internal accounting control mechanism design method

Enterprises are in the information era, the development of the environment must incessantlys uses advanced the efficient information management model to improve internal accounting control of operational efficiency and "Flat" management model applied to the organizational structure of 
the enterprises to optimize.

Large enterprises can between head office and branch establish network connection through the control of accounting information system software, realizes the head office and branch or subordinate enterprise accounting information between real-time interaction, improve the efficiency and accuracy of information transmission.

This will be conducive to the head office in a timely manner to the branch office business segments of the accounting information.

Companies operating in the raw materials procurement, sales and other involved in the process of price fluctuations can also through the network real-time transmission to the various departments, which is beneficial to improve the enterprise of each department, each link of unified decision making and control.

Facing the new tendency of the development of the network environment, the enterprise internal accounting control should be fully integrated the advantage of network technology, pay attention to the transformation of enterprise internal management system, control mechanism, and to establish a strong sense of risk prevention, both to promote accounting informationization, data sharing, also want to through the internal network supervision and administrative supervision to guard against the risk of accounting information disclosure, and realize the efficient transmission and use of accounting information within the enterprise.

\section{References}

[1] Pan Linyuan. Network environment under the enterprise accounting control system construction [J]. Modern state-owned enterprise research, 2015, (04): 31.

[2] Song Yun. Network accounting environment under the enterprise internal control system perfect [J]. Entrepreneurs heaven (second half issue), 2014, (06): 106-107.

[3] Wu Guobin. Construction of internal accounting control framework in network environment [J]. Friends of Accounting, 2013, (25): 51-54.

[4] Huang Liping. Network environment under the enterprise accounting internal control response measures [J]. China Management Information, 2013, (14): 31-32.

[5] Liu Yan. Analysis of the network environment of internal accounting control [J]. Finance and Economics (Academic Edition), 2010, (02): 221. 